УДК 613.262/22:614.31.07

DOI https://doi.org/10.15673/swonaft.v84i2.1888

\title{
СИРОВИНА РОСЛИННОГО ПОХОДЖЕННЯ ДЛЯ ВИРОБНИЦТВА ПРОДУКТІВ ДИТЯЧОГО ХАРЧУВАННЯ ФУНКЦІОНАЛЬНОГО ПРИЗНАЧЕННЯ
}

\author{
${ }^{1}$ Мазуренко І.К., Д-р техн. наук, професор, ${ }^{1}$ Yunbo Li acпірант, ${ }^{1}$ Shao Zhengzheng, aспірантка, \\ ${ }_{1}^{1}$ Мельник О. Ю. канд. техн. наук, доцент, ${ }^{2}$ Палвашова Г.І. канд. техн. наук, доцент \\ ${ }^{1}$ Сумський національний аграрний університет, м. Суми \\ ${ }^{2}$ Одеська національна академія харчових технологій, м. Одеса
}

Copyring (C) 2020 by author and the journal «Scientific Works»

This work is licensed under Vthe Creative Commons Attribution International License (CC By).

http://creativecommons.org/licenses/by/4.0

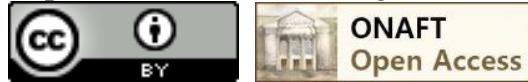

Анотація. Досліджено фізико-хімічний склад та показники якості сировини рослинного походження, яка традиційно вирощується в Украйні та Китаї. Результати досліджень увійдуть у дорожню карту комплексної програми створення гнучких технологій та асортименту продуктів функціонального призначення, тривалого зберігання для дітей різних вікових груп.

Ключові слова: дитяче функиіональне харчування, пієлонефрит, пневмонія, рослинна сировина, фізико-хімічні показники

\section{RAW MATERIALS OF VEGETABLE ORIGIN FOR PRODUCTION OF BABY NUTRITIONAL PRODUCTS FUNCTIONAL PURPOSE}

\author{
${ }^{1}$ I. Mazurenko, Dr. Sci. Tech, Professor, \\ ${ }^{1} \mathrm{Li}$ Yunbo, postgraduate student, ${ }^{1}$ Shao Zhengzheng, postgraduate student, \\ ${ }^{1}$ O. Melnyk, Ph.D., Associate Professor, ${ }^{2}$ H. Palvashova, Ph.D., Associate Professor \\ ${ }^{1}$ Sumy National Agrarian University, Sumy \\ ${ }^{2}$ Odessa National Academy of Food Technologies, Odesa
}

\begin{abstract}
Annotation. Nutrition is one of the most important factors influencing the health of the population. It ensures the normal development of children, promotes disease prevention, prolongs life and creates conditions for adequate human adaptation to the natural environment. Therefore, the issue of healthy nutrition of children is one of the most important in the implementation of social policy. Successfully solving the problem of baby food depends on creating the conditions for the production of quality and safe food.

The development of the domestic baby food industry is one of the most important issues that need to be addressed at the state level. Functional baby foods should contain as a component drugs or proposed to prevent or mitigate the disease of a child with special dietary needs, including in the case of congenital or acquired disorders of absorption of certain nutrients, their intolerance or certain diseases.

The quality of baby food is the degree of perfection of the properties and characteristics of baby food, which are able to meet the physiological needs of the child's body in food based on their chemical composition and energy value of raw materials and components, which are included in the prescription bookmark.

According to current regulations in Ukraine and China there are different requirements for quality and safety of products and raw materials used in food production.

Technological characteristics and physico-chemical composition of raw materials affect the use of processing processes, which allows to preserve the maximum of native substances. The results of research of physicochemical composition and quality indicators of raw materials of plant origin, which are traditionally grown in Ukraine and China, will be included in the roadmap of a comprehensive program to create flexible technologies and range of functional products, long-term storage for children of different ages.
\end{abstract}

Keywords: children's functional nutrition, pyelonephritis, pneumonia, vegetable raw materials, physicochemical parameters 
Народи України і Китаю поєднують традиційні дружні зв'язки. Між Україною і Китаєм успішно розвиваються відносини взаємовигідного співробітництва. Співпраця України з Китайською Народною Республікою у галузі науки і техніки є одним з пріоритетних напрямів двосторонніх відносин.

На сьогоднішній день обидві країни, як і всі країни світу стоять перед вирішенням глобальної проблеми здоров’я нації. Відомий фактор, що чужих дітей не буває, а харчування особливо дітей та молодого покоління $є$ одним з гарантів здоров я людини.

Захворюваність населення на пієлонефрит та пневмонію стало гострою проблемою у всьому світі, особливо у дітей різного віку. Виникнення хвороб нирок, та інфекційних хвороб легенів, особливості їх поширення визначаються природно-екологічними та соціально-економічними чинниками, значення останніх 3 якіх набуває все більшого значення через вплив способу життя, доходів населення, житлових умов, структури харчування та ряду інших чинників [1].

За даними Державної служби статистики України, рис. 1, на 1 січня 2019 року чисельність населення України складає 42353201 людини, без врахування тимчасово окупованої територій, Автономної Республіки Крим і міста Севастополь Проте чисельність українців стабільно зменшується, народжуваність 2017 року становила 10,3\% (189-те місце у світі), смертність - 14,4\% (5-те місце у світі), природний приріст - 0,41\% (220-те місце у світі) [2].

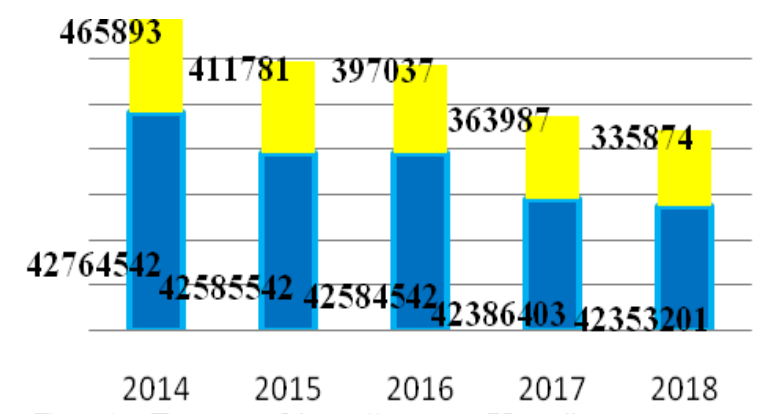

Рис. 1 - Демографічний стан в України за роками

- Кількість населення Кількість народжених

Одночасно статистичні данні свідчать, табл. 1, про високий рівень захворюваності населення, особисто дітей та підлітків. На примірнику класу хвороби сечостатевої системи видно тенденцію росту захворювання, за останні п’ять років.

Таблиця 1 - Кількість заресстрованих з захворюванням сечостатевої системи в Україні

\begin{tabular}{|c|c|c|}
\hline \multirow{2}{*}{ Рік } & \multicolumn{2}{|c|}{ Кількість уперше зареєстрованих випадків захворювання } \\
\cline { 2 - 3 } & Особи віком 18 років і старші & Діти та підлітки віком від 0 до 17 років включно \\
\hline 2015 & 1723742 & 187147 \\
2016 & 1760846 & 191007 \\
2017 & 1779318 & 193890 \\
2018 & 1816683 & 196289 \\
2019 & 1853017 & 199234 \\
\hline
\end{tabular}

Згідно зі статистичними даними Державного закладу "Центр медичної статистики Міністерства охорони здоров'я України", щорічно в Україні реєструється близько 90000 випадків пневмоній серед дітей у віці від 0 до 17 років, а кожні три дні в Україні від пневмонії помирає одна дитина у віці до 4 років. У Харківській області зареєстровано пневмонія серед всього населення протягом 2017 року - 12253 випадків, з них 3841 випадок серед дітей від 0 до 17 років. У 2016 році на пневмонію перехворіло 15703 особи різних вікових груп, в тому числі 4588 дітей. Захворюваність, кількість випадків на кожні 100 тис. населення серед дорослого населення склала 372,33 випадки в 2017 році і

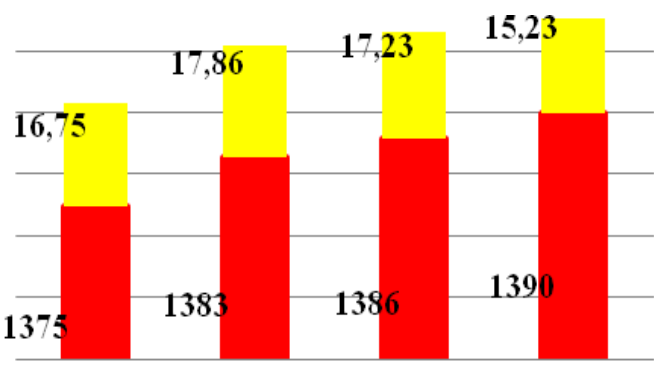

Рис. 2 - Демографічний стан у Китаю, за роками

Кількість населення мільярд Кількість народжених мільон
488,1 випадків у 2016 році. Показники захворюваності дитячого населення більш ніж в два рази вище і відповідно рівні 901,12 випадків у 2017 році і 1077,59 в 2016 році. Смертність від пневмонії зросла 3 11,7 у 2017 році до 15,3 у 2018 році на 100 тис. населення. Впродовж 2019 року в Україні захворіло на гострі інфекційні захворювання верхніх дихальних шляхів, пневмонію та грип, абсолютна чисельність дітей 232715 віком від 0 до 17 років. Абсолютна чисельність смертності дітей 3 такою патологією склала 69 [3]. 
За статистичними даними Китайської Народної Республіки станом на 1 січня 2019 року чисельність населення складає 1.390 мільярд, при цьому народжуваність кожного року зростає приблизно від $5 \%$ до $8 \%$,, в 2017 році народжуваність незначно знизилась. Данні про чисельність населення та народжуваність в КНР наведено на рис. 2.

Кожного року спеціальна науково-медична комісія Китаю проводить обстеження населення різних вікових груп на виявлення людей з захворюваннями нирок. Протягом трьох років кількість людей 3 захворюваннями норок зросло більш ніж $11 \%$. У 2015 року цей показник складав 119,63 мільйонів людей, в 2017 році 133,0 мільйонів. При обстежені дітей віком від 2 до 14 років виявлено кожного року 2,0 мільйона з захворюванням нирок. Тільки в провінції Хєнань, схід центральної частини Китаю кожного року зафіксовано 200 тисяч дітей з захворюваннями нирок [4 - 6].

У доповіді Дитячого фонду ООН (ЮНІСЕФ), якій був опублікований в кінці 2019 року, пневмонія названа «прихованою епідемією». «Кожен день від пневмонії помирають приблизно 2200 дітей у віці до п'яти років. Йдеться про захворювання яке виліковується, яке в принципі, можливо запобігти», - заявила Виконавчий директор ЮНІСЕФ Генрієтта Фор. Вона підкреслила, що сьогодні необхідно виділяти більше коштів на боротьбу з цією хворобою і мобілізувати міжнародну підтримку. Протягом 20182019 років від пневмонії загинуло більше дітей у віці до п'яти років, ніж від малярії, діареї та кору. Особливому ризику піддаються діти, які недоїдають і не мають доступу до чистої води, або живуть в регіонах з високим рівнем забруднення повітря. Більше половини всіх випадків смерті дітей від пневмонії доводиться на п'ять країн: Нігерію - 162 тисячі, Індію - 127 тисячі, Пакистан - 58 тисячі, Демократичну Республіку Конго - 40 тисяч і Ефіопію 32 тисячі. У десятку країн з найвищим рівнем смертності від пневмонії входить і Китай, де щороку від інфекції помирають 18 тисяч дітей [7]. Статистичні данні не відображають ситуацію, яка склалась з захворюванням людей на Коронавірусну інфекцію COVID-19.

Харчування хворої дитини в різні періоди стадії захворювання, особливо коли асортимент їжі впливає на функціональні дії організму є гострою проблемою, яка може бути вирішена шляхом залучення досліджень різних галузей науки. Використання сировини рослинного походження в комплексі з лікарськими рослинами або екстрактів лікарських рослин дозволяє створювати продукти лікувально-профілактичного призначення для дітей різних вікових груп. Таке харчування можливо застосовувати в період ремісії захворювання дитини, а в деяких випадках є основою лікування.

В основі кожної технології виробництва продуктів харчування та якості готової продукції перш за все знаходяться показники фізико-хімічної характеристики сировини, ї̈ якість, безпечність та функціональні властивості. Особлива увага придивляється сировині яка використовується при виробництві продуктів для харчування дітей та продуктів функціонального призначення. Сировина, яка використовується для виробництва даної групи продукції повинна відповідати обов'язковим параметрам безпечності та мінімальним специфікаціям якості, не може бути вироблена, а також містити генетично модифіковані організми. Одночасно забороняється використання сировини, що містить гормональні препарати, антибіотики, залишки важких металів, пестицидів, радіонуклідів та інших небезпечних речовин, вміст яких перевищує максимально допустимі рівні залишків у дитячому харчуванні. Враховуючи географічні зони вирощування, які кардинально впливають на фізико-хімічний та реологічні показники рослинної сировини, було прийнято рішення на першому етапі досліджень вивчити технологічні показники сировини рослинного походження і вибрати оптимальні.

Дослідження фізико-хімічних показників сировини $\epsilon$ необхідними при формуванні технологічного процесу. Перш за все, це впливає на визначення параметрів процесу, циклічність технології, що дає можливість поточності перероблення сировини, не допускання псування та прямої економії енергоресурсів. По друге основною метою перероблення сировини рослинного походження є збереження нативних речовин, які в подальшому будуть основним компонентом продукту з заданою дією.

Сировину для дослідження відбирали одного сорту та з однієї партії. Одночасно проводили дослід у трьох паралелях, арифметичним шляхом виводили середнє значення. Вірогідність значень складає більше або дорівнює $95 \%$. В сировині рослинного походження, досліджували вміст масової частки органічних та неорганічних речовин, що характерно впливають на способи виробництва, характеристику готового харчового продукту, у тому числі його функціональність та властивість, характерні ознаки, склад (харчова та енергетична цінність (калорійність)) та термін придатності.

Дослідження овочів та фруктів проводилось виключно 3 урахуванням наступних факторів сировинна повинна бути антиалергенною та широко використовуватися в раціонах харчування дітей, як в Украйні так і в Китаї. У кожному сорті досліджували об'єднану точкову пробу масою 5 кг. Дослідження проводили згідно з методами та методиками, які наведені в чинних нормативних документах [8 - 20]. 
Для порівняльної характеристики відібрали по три сорту гарбуза, моркви, яблук, груш які вирощуються в Україні і Китаї, а також плоди які не вирощують в Україні - банани та манго.

Кулінарно підготовлене пюре гарбуза дозволено включати в раціон харчування дитини у вигляді прикорму з 5 місяців. Фізико-хімічні показники гарбузу сортів «Ждана», «Доля», «Диво», які традиційно вирощують в Україні та сорти «Miben»(蜜本南瓜), «Big grinding disc» (大磨盘南瓜), «Kangua» 砍瓜, які традиційно вирощують в Китаї наведено на рис. 3 та в табл.2.

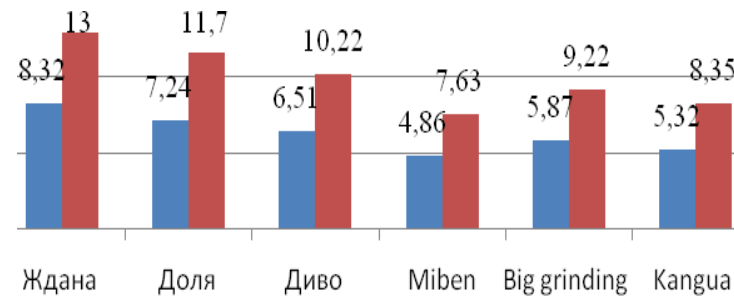

Рис. 3 - Масова частка моно-і дисахаридів розчинних сухих речовин, в плодах гарбуза, \%

моно-і дисахариди розчинні сухи речовини

Гарбуз українського сорту «Ждана» містить максимальну кількість моно-і дисахаридів $8,32 \%$ серед досліджених, проте гарбуз китайського сорту «Big grinding disc大磨盘南瓜》 максимально моно-і дисахаридів 5,87 \% серед досліджених. На нашу думку це обумовлено характеристиками грунтів, кліматичними умовами та різними строками збору.

Одночасно можливо припустити, що рецептори людей різних етнічних груп по різному оцінюють сенсорні показники. Так гарбуз сорту Big grinding disc 大磨盘南瓜 3 масовою часткою моно-і дисахаридів 5,87 \% вважається солодким у людей азіатських країн, проте люди європейських країн мають іншу думку. На прикладі гарбузу сорту Ждана, показник вмісту моно-і дисахаридів вище приблизно на $42 \%$ і вважається солодким.

Паралельно було проведено дослідження інших показників хімічного складу гарбузу наведених сортів. Порівняльні характеристики наведено в табл. 2.

Таблиця 2 - Порівняльний хімічний склад гарбузу $(\mathbf{n}=3, \mathrm{P} \geq 0,95)$

\begin{tabular}{|c|c|c|c|c|c|c|c|}
\hline \multirow{2}{*}{ Назва сорту } & \multirow{2}{*}{$\begin{array}{c}\text { Масова } \\
\text { частка } \\
\text { білку, г }\end{array}$} & \multirow{2}{*}{$\begin{array}{c}\text { Масова } \\
\text { частка } \\
\text { пектину, г }\end{array}$} & \multicolumn{5}{|c|}{ Масова частка вітамінів, мг \% } \\
\hline & & & $\beta$-каротин & $\mathrm{C}$ & $\mathrm{B}_{1}$ & $\mathrm{~B}_{2}$ & PP \\
\hline \multicolumn{8}{|c|}{ Сорти які вирощуються в Україні } \\
\hline Ждана & 1,0 & 1,8 & 9,8 & 8,9 & 0,041 & 0,040 & 0,49 \\
\hline Доля & 1,0 & 1,8 & 9,5 & 8,0 & 0,04 & 0,040 & 0,45 \\
\hline Диво & 0,8 & 1,4 & 7,8 & 6,5 & 0,04 & 0,039 & 0,43 \\
\hline \multicolumn{8}{|c|}{ Сорти які вирощуються в Китаї } \\
\hline Miben蜜本南瓜 & 0,9 & 1,8 & 9,6 & 8.6 & 0,04 & 0,038 & 0,48 \\
\hline $\begin{array}{l}\text { Big grinding disc } \\
\text { 大磨盘南瓜 }\end{array}$ & 1,0 & 1,9 & 9,9 & 8,9 & 0,04 & 0,04 & 0,5 \\
\hline Kangua 砍瓜 & 1,0 & 1,9 & 9,8 & 8,7 & 0,04 & 0,4 & 0,49 \\
\hline
\end{tabular}

Показники хімічного складу досліджених сортів гарбузу, які вирощуються в Китаї та Україні фактично схожі з деякіми незначними коливаннями, що дає можливість стверджувати про впровадження цих сортів гарбузу у виробництво продуктів для дітей.

В гарбузі не міститься жиру, тому харчову та енергетичну цінність розраховували без використання цього показника. Середня енергетична цінність, калорійність гарбузу сортів, які вирощується в Україні, складає 50,6 ккал або 212 кДж. Відповідно середня енергетична цінність, калорійність гарбузу сортів, які вирощується у Китаї складає 37,4 ккал або 157 кДж. Така розбіжність в показниках не є значною, та відповідає встановленим вимогам щодо сортів гарбузу, які використовуються при виробництві продуктів для дітей та функціонального призначення

Використання для виробництва пюреподібних продуктів гарбузу селекції обох країн дозволяє встановлювати єдині вимоги щодо технологічності. Враховуючи те, що фактично схожі кора, щільність та колір м'якоті, дозволить застосувати режими очищення та параметри термічного оброблення не залежно від сортів селекції гарбуза, але після проведення дослідження фізико-хімічних показників.

Моркву та кулінарне підготовлене пюре відносять до продуктів, які застосовують в раціоні лікувального харчування. Рекомендовано широке застосування не тільки при нестачі вітамінів групи А , при аліментарних захворюваннях, включаючи інфекційні та неінфекційні захворювання легенів. Одночасно рекомендовано включати в раціон харчування дитини віком до одного року від 50 до 70 г пюре з моркви на добу, дитині після року народження доза підвищується до 150 г на добу. 
Для проведення дослідження порівняльної характеристики плодів моркви, було відібрано сорти «Болтекс», «Лагуна», «Нантська» які традиційно вирощують в Україні та сорти «Jingbian Carrots (靖边胡 萝卜)», 《Jinghong five inch Carrots (京红五寸胡萝卜)», «Hongxin No. 6 (红芯六号)», які вирощують у Китаї. Співвідношення масової частки розчинних сухих речовин та вмісту масової частки моно-і дисахаридів у моркві різних сортів, наведено на рис.4. Порівняльні показники хімічного складу моркви наведено табл. 3.

Морква сорту «Лагуна» відмічається найкращими за показниками вмісту енергетичної цінності, особливо за вмістом масової частки білку, вуглеводів та пектину, а також за вмістом деяких вітамінів. Практично всі плоди моркви, які вирощені в Китаї мають високі показники вмісту вуглеводів в середньому на $10 \%$, вмісту пектину на $20 \%$, а середній показник масової частки вітаміну С, вищі ніж у плодах Української селекції майже на 100 \%.

Наведені показники знаходяться практично в одному діапазоні. Енергетичну цінність, калорійність моркви, сортів, які вирощені в Україні та Китаї було обчислено стандартним принципом.

Середня енергетична цінність, калорійність

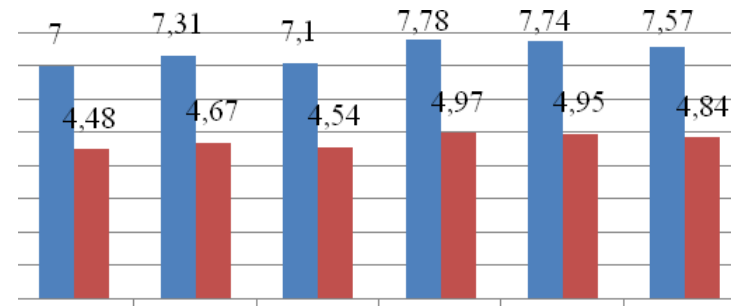

Болтекс Лагуна Нантська Jingbian Jinghong Hongxin Carrots five inch No.6

Carrots
Pис. 4 Масова частка сухих речовин, моно-i дисахар ндів в моркві, \%

пухі речовини воно-і дисахариди моркви сортів які вирощені в Україні складає 34,35 ккал або 143,9 кДж, відповідно калорійність моркви сортів які вирощені у Китаї складає 36,33 ккал або 152,2кДж. Дослідженні плоди моркви, які вирощені в Україні та Китаї за фізико-хімічними показниками, можуть бути використані, як сировина для виробництва продуктів дитячого харчування, функціонального призначення.

Таблиця 3 - Порівняльний хімічний склад моркви (n=3, P $\geq 0,95)$

\begin{tabular}{|l|c|c|c|c|c|c|c|c|c|c|}
\hline \multirow{2}{*}{ Назва сорту } & \multicolumn{7}{c|}{ Масова частка, Г } & \multicolumn{3}{c|}{ Масова частка вітамінів, мг \% } \\
\cline { 2 - 9 } & жиру & білку & вуглеводів & пектину & $\beta$-каротин & С & $\mathrm{B}_{1}$ & $\mathrm{~B}_{2}$ & РР \\
\hline \multicolumn{7}{|c|}{ Сорти які вирощують в Україні } \\
\hline Болтекс & 0,1 & 1,3 & 6,9 & 0,6 & 8,26 & 5,7 & 0,06 & 0,06 & 1,2 \\
\hline Лагуна & 0,1 & 1,4 & 7,2 & 0,7 & 8,40 & 5,9 & 0,10 & 0,02 & 1,2 \\
\hline Нантська & 0,1 & 1,3 & 7,0 & 0,6 & 8,25 & 5,8 & 0,08 & 0,02 & 1,2 \\
\hline \multicolumn{7}{|c|}{ Сорти які вирощують в Китаї } \\
\hline Jingbian Carrots (靖边胡萝卜) & 0,2 & 1,0 & 7,7 & 0,8 & 8,96 & 11,5 & 0,04 & 0,03 & 1,2 \\
\hline $\begin{array}{c}\text { Jinghong five inch Carrots (京红 } \\
\text { 五寸胡萝卜) }\end{array}$ & 0,2 & 1,1 & 7,7 & 0,8 & 8,10 & 13,0 & 0,04 & 0,03 & 1,2 \\
\hline Hongxin No. 6 (红芯六号) & 0,2 & 1,0 & 7,5 & 0,7 & 11,0 & 12,9 & 0,04 & 0,03 & 1,2 \\
\hline
\end{tabular}

Одним з проблемних процесів перероблення моркви є очищення, з використання карборундового миття, чи паротермічне очищення, або послідовність двох процесів, що є складно, не зручно та економічно не вигідно. В результаті проведених досліджень відібрано сорти моркви, які вирощується в Україні та Китаї, та можуть бути запропоновані в уніфікованій гнучкій технології виробництва продуктів функціонального призначення для дітей.

Враховуючи те, що для прикорму дитини в основному використовують яблука зелені, нами були вибрані для дослідження яблука зелених сортів «Голден Резістент», «Сніжний Кальвіль», «Скіфське золото» які традиційно вирощують в Україні та сорти яблук «Gansu Yinchuan city» (甘肃 省银川市青苹果), «Shandong Qixia county» (山东省 栖霞县青苹果), «Henan Sanmenxia» (河南省三门峡 市青苹果), які традиційно вирощують в Китаї. Вміст масової частки моно-і дисахаридів в яблуках сортів з України та Китаю наведено на рис. 5.

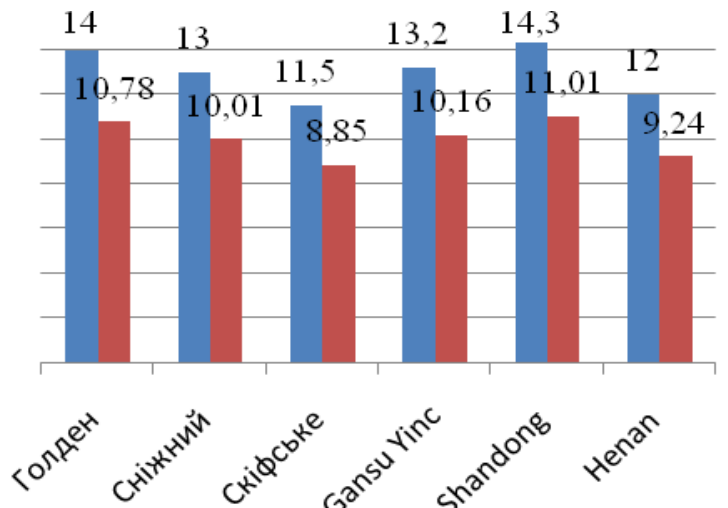

Рис. 5 Масова частка сухих речовин, моноі дисахаридів в яблуках, \%

пухіречовини моно-і дисахариди 
Сорт яблук української селекції Голден Резістент та сорт яблук селекції Китаю - Shandong Qixia county山东省栖霞县青苹果, за показниками наведеними на рис. 5, знаходяться фактично в одному діапазоні. Яблука інших сортів, які досліджували мають не значні розбіжності.

Дослідження інших показників хімічного складу яблук також проводили паралельно. Порівняльні характеристики наведено в табл. 4. Енергетичну цінність, калорійність яблук, сортів, які вирощуються в Україні та Китаї було обчислено стандартним принципом. Середня енергетична цінність, калорійність яблук сортів які вирощені в Україні складає 54,4 ккал або 227,9 кДж, відповідно калорійність яблук сортів які вирощені у Китаї складає 55,8 ккал або 234 кДж.

Необхідно відмітити, хімічний склад сортів яблук, які досліджували практичного однакові, що дає можливість стверджувати про впровадження єдиних вимог до яблук, які використовуються при виробництві продуктів тривалого зберігання для харчування дітей та продуктів функціонального призначення в Україні та у Китаї.

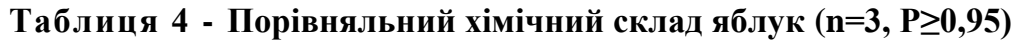

\begin{tabular}{|c|c|c|c|c|c|c|c|}
\hline \multirow{2}{*}{ Назва сорту } & \multirow{2}{*}{$\begin{array}{c}\text { Масова } \\
\text { частка } \\
\text { білку, г }\end{array}$} & \multirow{2}{*}{$\begin{array}{c}\text { Масова } \\
\text { частка } \\
\text { пектину, г }\end{array}$} & \multicolumn{5}{|c|}{ Масова частка вітамінів, мг \% } \\
\hline & & & $\beta$-каротин & $\mathrm{C}$ & $\mathrm{B}_{1}$ & $\mathrm{~B}_{2}$ & $\mathrm{PP}$ \\
\hline \multicolumn{8}{|c|}{ Сорти які вирощуються в Україні } \\
\hline Голден Резістент, & 0,8 & 1,9 & 0,01 & 10,2 & 0,01 & 0,01 & 0,1 \\
\hline Сніжний Кальвіль & 0,7 & 1,6 & 0,02 & 9,0 & 0,01 & 0,01 & 0,1 \\
\hline Скіфське золото & 0,8 & 1,4 & 0,02 & 7,2 & 0,01 & 0,01 & 0,1 \\
\hline \multicolumn{8}{|c|}{ Сорти які вирощуються в Китаї } \\
\hline $\begin{array}{l}\text { Gansu Yinchuan city } \\
\text { 甘肃省银川市青苹果 }\end{array}$ & 0,8 & 1,8 & 0,01 & 9,0 & 0,01 & 0,01 & 0,1 \\
\hline $\begin{array}{c}\text { Shandong Qixia county山东 } \\
\text { 省栖霞县青苹果 }\end{array}$ & 0,8 & 1,9 & 0,01 & 7,2 & 0,01 & 0,01 & 0,1 \\
\hline $\begin{array}{c}\text { Henan Sanmenxia } \\
\text { 河南省三门峡市青苹果 }\end{array}$ & 0,6 & 1,5 & 0,01 & 7,8 & 0,01 & 0,01 & 0,1 \\
\hline
\end{tabular}

Груша практично не викликає алергію і вводиться в раціон харчування дитини однією 3 перших серед фруктів. Фрукт добре засвоюється дитячим організмом, якщо дотримані всі правила кулінарної обробки i приготування. Вживання груш сприяє зняттю нервової напруги, підвищенню настрою, сприятливо впливає на роботу внутрішніх органів, a особливо серця i шлунковокишкового тракту. Груша виводить токсини і важкі метали, а також стабілізує захисні функції організму. Можна вважати, що фрукт ефективно впливає на одужання при інфекційних захворюваннях

При проведенні досліджень плодів груш, рис. 6, табл. 5, було відібрано сорти української селекції «Марія», «Ніка», «Кафедральна», та сорти груш «Snowflake Pear (雪花梨)», «Jing Bai
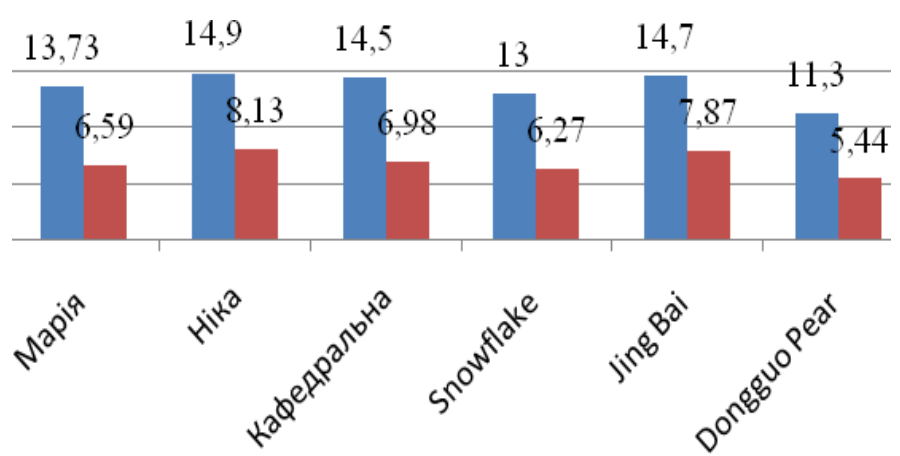

Рис. 6 Масова частка сухих речовин, моно-і

дисахаридів у грушах, \%

шухіречовини моно-і дисахариди

Pear (京白梨)», «Dongguo Pear (冬果梨)», які вирощують у Китаї. Відібрані сорти груш, які вирощуються в Україні та Китаї практично схожі, за виключенням маси та геометричних розмірів плодів, груша сорту «Snowflake Pear (雪花梨)», має значно більші розміри, проте на технологічність, та ускладнення процесу перероблення ці показники не впливають.

Необхідно відмітити, що в процесі дослідження технологічної характеристики груш, було відібрано сорти в яких м'якоть має білий колір та шкірочка від жовтого до коричного. Плоди 3 таким кольором практично не викликають алергію в організмі дитини, та можуть бути запровадженні, як для загального так і функціонального харчування.

Діапазон показників хімічного складу груш які вирощені в Україні та Китаї незначно відрізняться. 
Таблиця 5 - Порівняльний хімічний склад груш (n=3, P $\geq 0,95)$

\begin{tabular}{|c|c|c|c|c|c|c|c|c|c|}
\hline \multirow{2}{*}{ Назва сорту } & \multicolumn{4}{|c|}{ Масова частка, г } & \multicolumn{5}{|c|}{ Масова частка вітамінів, мг \% } \\
\hline & жиру & білку & вуглеводів & пектину & $\beta$-каротин & $\mathrm{C}$ & $\mathrm{B}_{1}$ & $\mathrm{~B}_{2}$ & PP \\
\hline \multicolumn{10}{|c|}{ Сорти які вирощують в Україні } \\
\hline Марія & 0,6 & 0,4 & 10,3 & 0,7 & 0,09 & 5,4 & 0,01 & 0,02 & 0,3 \\
\hline Ніка & 0,1 & 0,6 & 12,7 & 0,9 & 0,09 & 5,8 & 0,01 & 0,01 & 0,3 \\
\hline Кафедральна & 0,3 & 0,4 & 10,9 & 0,8 & 0,07 & 5,6 & 0,01 & 0,01 & 0,3 \\
\hline \multicolumn{10}{|c|}{ Сорти які вирощують в Китаї } \\
\hline $\begin{array}{c}\text { Snowflake Pear 雪 } \\
\text { 花梨 }\end{array}$ & 0,1 & 0,2 & 9,8 & 0,8 & 0,07 & 4,1 & 0,01 & 0,01 & 0,3 \\
\hline Jing Bai Pear 京白梨 & 0,5 & 0,2 & 12,3 & 0,7 & 0,06 & 3,9 & 0,02 & 0,02 & 0,3 \\
\hline Dongguo Pear冬果梨 & 0,2 & 0,4 & 8,5 & 0,6 & 0,07 & 6,0 & слід & 0,03 & 0,3 \\
\hline
\end{tabular}

Масова частка жиру у плодах, які вирощені в Україні вище на 20 \%, білку більше на 30 \%, вуглеводів на $10 \%$. Також відрізняється вміст деяких вітамінів, масова частка вітаміну С на $20 \%$ вище, вміст $\beta$ каротину на 30 \% у грушах які вирощені в Україні.

Наведені показники знаходяться практично в одному діапазоні. Середня енергетична цінність, калорійність груш сортів які вирощені в Україні складає 50,0 ккал або 209,5 кДж, відповідно калорійність груш сортів які вирощені у Китаї складає 44,18 ккал або 185,11 кДж. Дослідженні плоди груш, які вирощені в Україні та Китаї за фізико-хімічними показниками, можуть бути використані, як сировина для виробництва продуктів дитячого харчування, функціонального призначення.

Паралельно були проведені дослідження плодів, які не вирощують в Україні, таких як банан, манго. Дослідження проводили за методами та методиками, які використовували в попередніх дослідженнях.

Банани вирощуються в Китаї круглий рік на відміну від України. Враховуючи те, що їх вирощують як для годівлі тварин так і для харчування людей, було досліджено сорти - «Banana Gongjiao»(贡蕉), «Banan"Pei-Chiao"»(北蕉.), «Malaysian Red Banana» (马来西亚红香), які реалізують в торгівельній мережі для споживачів. Результати дослідження наведено в табл. 6.

Таблиця 6 - Хімічний склад бананів $(n=3, P \geq 0,95)$

\begin{tabular}{|c|c|c|c|}
\hline \multirow[b]{2}{*}{ Назва показника } & \multicolumn{3}{|c|}{ Назва сорту } \\
\hline & $\begin{array}{c}\text { Banana Gongjiao } \\
\text { 贡蕉 }\end{array}$ & $\begin{array}{c}\text { Malaysian Red Banana } \\
\text { 马来西亚红香蕉 }\end{array}$ & $\begin{array}{l}\text { Pei-Chiao } \\
\text { 北蕉 }\end{array}$ \\
\hline Масова частка розчинних сухих речовин, \%, & 20,0 & 21,5 & 21,0 \\
\hline Масова частка моно-і дисахаридів, \%, & 15,4 & 16,5 & 16,1 \\
\hline Масова частка білку, г & 1,5 & 1,5 & 1,5 \\
\hline Масова частка жиру, г & 0,2 & 0,2 & 0,2 \\
\hline Масова частка пектину, г & 1,7 & 1,8 & 1,5 \\
\hline Масова частка $\beta$-каротин, мг \% & 0,01 & 0,02 & 0,01 \\
\hline Масова частка вітаміну C, мг \% & 19,0 & 19,2 & 18,6 \\
\hline Масова частка вітаміну $\mathrm{B}_{1}$, мг \% & 0,07 & 0,07 & 0,07 \\
\hline Масова частка вітаміну $\mathrm{B}_{2}$, мг \% & 0,02 & 0,02 & 0,02 \\
\hline Масова частка вітаміну РР, мг \% & 0,1 & 0,1 & 0,1 \\
\hline
\end{tabular}

Показники хімічного складу бананів, табл. 6 та яблук сортів які досліджували, табл.4, практично схожі, за виключенням вмісту вітаміну С . Масова частка вітаміну С, в банані на 125 \% більше ніж в яблуках, проте за сенсорними показниками, за смаком банан набагато солодший. Одночасно в банані міститься незначна кількість жиру, якій відсутній, або присутні сліди в інших фруктах. Середня енергетична цінність, калорійність бананів сортів які вирощені у Китаї складає 91,3 ккал або 382,5 кДж.

Банан не тільки смачний, але і корисний плід, якій не викликає алергічну реакцію організму. В Україні широко використовується у виробництві пюре банану асептичного консервування, яке поступає за імпортом в асептичних мішках, що виготовлені з полімерних матеріалів 3 клапаном, місткістю від 0,20 $\mathrm{M}^{3}$ до 2,25 м м $^{3}$, які упаковані у захисні металеві бочки, (пакування типу «Bag-in-barrel»). В основному імпортують асептичне пюре банану з Китаю, Коста-Рика, Індії. Було досліджено зразки пюре різних постачальників, Shanghai Jinghuai Biotechnology Co., Ltd.( 上海靖淮生物技术有限公司) Китай, Paradise Ingredients commercial Team, Коста-Рика, JADLI FOODS PVT.LTD Індія 
За технологічними та сенсорними параметрами, пюре банану асептичного консервування має кремовий колір за всією масою, однорідну протерту консистенцію, в деяких зразках відмічається незначне відшаровування рідини. Смак та запах натуральні, добре виражений, властивий банану, після термічного оброблення.

Результати досліджень хімічного складу показників пюре банану асептичного консервування наведено в табл. 7.

Враховуючи те, що пюре це продукт - напівфабрикат, який використовується для виробництва інших продуктів харчування, в таблицю добавленні показники, які необхідні відповідно регламентам міжнародної стандартизації. В пюре додатково досліджують та контролюють, масову частку титрованих кислот, (у розрахунку на лимонну кислоту), масова частку летких кислот, масова частку етилового спирту, масову частку мінеральних домішок та показник рН. Ці показники характеризують якість і в деякій мірі безпечність продукту.

Таблиця 7 - Хімічний склад пюре банану асептичного консервування $(\mathrm{n}=3, \mathrm{P} \geq 0,95)$

\begin{tabular}{|c|c|c|c|c|c|c|}
\hline \multirow{3}{*}{ Назва показника } & \multicolumn{6}{|c|}{ Зразки постачальників } \\
\hline & \multicolumn{2}{|c|}{$\begin{array}{c}\text { Biotechnology Co. Ltd. } \\
\text { (上海靖淮生物技术有限公司) } \\
\text { Китай } \\
\end{array}$} & \multicolumn{2}{|c|}{$\begin{array}{l}\text { Paradise Ingredients } \\
\text { commercial Team, } \\
\text { Коста-Рика }\end{array}$} & \multicolumn{2}{|c|}{$\begin{array}{l}\text { JADLI FOODS } \\
\text { PVT.LTD } \\
\text { Індія }\end{array}$} \\
\hline & № 1 & № 2 & № 1 & № 2 & № 1 & № 2 \\
\hline $\begin{array}{l}\text { Масова частка розчинних сухих } \\
\text { речовин, \%, }\end{array}$ & 23,0 & 23,0 & 22,0 & 22,0 & 22,6 & 22,6 \\
\hline Масова частка білку, г & 1,5 & 1,5 & 1,5 & 1,5 & 1,5 & 1,5 \\
\hline Масова частка жиру, г & 0,2 & 0,2 & 0,2 & 0,2 & 0,2 & 0,2 \\
\hline Масова частка пектину, г & 1,4 & 1,4 & 1,3 & 1,3 & 1,3 & 1,3 \\
\hline Масова частка $\beta$-каротин, мг \% & 0,01 & 0,01 & 0,01 & 0,01 & 0,01 & 0,01 \\
\hline $\mathrm{pH}$ & 4,2 & 5,1 & 4,2 & 5,0 & 4,2 & 5,0 \\
\hline \begin{tabular}{llr} 
Масова & частка & \multicolumn{2}{c}{ титрованих } \\
кислот (у розрахунку на \\
лимонну кислоту), \%
\end{tabular} & 0,70 & 0,45 & 0,70 & 0,45 & 0,70 & 0,45 \\
\hline Масова частка летких кислот, \% & 0,01 & 0,01 & 0,01 & 0,01 & 0,01 & 0,01 \\
\hline Масова частка етилового спирту, \% & 0.17 & 0.17 & 0,17 & 0,17 & 0,19 & 0,19 \\
\hline $\begin{array}{l}\text { Масова частка } \\
\text { домішок, \% }\end{array}$ & 0,01 & 0,01 & 0,01 & 0,01 & 0,01 & 0,01 \\
\hline Масова частка вітаміну C, мг \% & 15,5 & 15,5 & 14,9 & 14,9 & 15,3 & 15,3 \\
\hline Масова частка вітаміну $\mathrm{B}_{1}$, мг \% & 0,05 & 0,05 & 0,05 & 0,05 & 0,05 & 0,05 \\
\hline Масова частка вітаміну $\mathrm{B}_{2}$, мг \% & 0,01 & 0,01 & 0,01 & 0,01 & 0,01 & 0,01 \\
\hline Масова частка вітаміну РР,мг \% & 0,08 & 0,08 & 0,08 & 0,08 & 0,08 & 0,08 \\
\hline
\end{tabular}

При дослідженні встановлено, що пюре виробляють як з додавання так і без додавання лимонної кислоти, 3 промислових партій було відібрано пюре різних постачальників та пронумеровано. Пюре зразок № 1 містить низький показник рН та високий вміст масової частки титрованих кислот, проте пюре зразок № 2 містить показник рН в 1,5 рази вище, а вміст масової частки титрованих кислот 1,5 нижчі. Такі результати, це наслідок технологічних операцій та рецептурних закладок виробництва. Для мікробіологічної стабільності та промислової стерильності пюре напівфабрикат підкислюють лимонною кислотою, що призводить до зниження показника $\mathrm{pH}$, в результаті чого знижують параметри режиму теплової стерилізації в потоці, або не додають кислоту та підвищують параметри режиму стерилізації. Обидва зразка відповідають вимогам, але стверджувати про стовідсоткову натуральність пюренапівфабрикату, в якій в процесі технологічного циклу додали кислоту лимонну (Е330), або іншу кислоту не є коректним. В той же час остатня кількість масової частки лимонної або іншої кислоти нормується продуктах, особливо в продуктах функціонального призначення та продуктах для дітей.

При порівняні хімічного складу банану та пюре бананового напівфабрикату відмічається незначна різниця в співвідношенні масової частки розчинних сухих речовин. В пюре напівфабрикаті цей показник вище як у постачальників з Китаю та і інших країн. На нашу думку це пов'язано по-перше 3 тим , що використовується при переробленні банани різних сортів одночасно, по-друге в технологічному циклі використовується переробка банану без зняття шкури. Одночасно відмічається зниження масової частки вітамінів в пюре-напівфабрикаті, в середньому показники знижено на 19 \%, це обумовлено термічною обробкою сировини та пюре в процесі стерилізації в потоці. Якщо порівнювати середню 
енергетичну цінність і калорійність бананів та пюре напівфабрикату то різниця не велика та складає 97,9 ккал або 391,6 кДж.

Манго, екзотичний фрукт для України, в той же час дуже корисний для здоров'я дитини. Плід використовується в раціоні харчування як допоміжний засіб при інфекційному захворюванні легенів, а також при лікуванні гострого респіраторного захворювання та при лікуванні очних хвороб. Необхідно також відмітити, що плід манго легко засвоюється організмом дитини, укріплює імунітет, сприяє розвитку мозкової діяльності. В той же час лікарі педіатри та вчені неонатологи висловлюють різні бачення, стосовно включення в раціон харчування дитини плоду манго. Вчені США та Азії вважають можливим включення пюре 3 манго у вигляді прикорму дитині від 4 до 6 місяців, або 38 місяців народження, українські вчені вважають можливим включати до раціону пюре 3 манго дітям, після 12 місяців народження.

Таблиця 8 - Хімічний склад манго $(n=3, P \geq 0,95)$

\begin{tabular}{|c|c|c|c|c|c|c|c|c|c|}
\hline \multirow[b]{2}{*}{ Назва сорту } & \multicolumn{4}{|c|}{ Масова частка, г } & \multicolumn{5}{|c|}{ Масова частка вітамінів, мг \% } \\
\hline & жиру & білку & вуглеводів & пектину & $\begin{array}{c}\beta- \\
\text { каротин }\end{array}$ & $\mathrm{C}$ & $\mathrm{B}_{1}$ & $\mathrm{~B}_{2}$ & PP \\
\hline \multicolumn{10}{|c|}{ Сорти які вирощують в Україні } \\
\hline $\begin{array}{c}\text { Tainung No.1 (台农 } \\
\text { 一号) }\end{array}$ & 0,2 & 0,6 & 7,01 & 0,5 & 9,0 & 41,0 & 0,01 & 0,04 & 0,5 \\
\hline $\begin{array}{c}\text { «Mangifera indica } \\
\text { Linn.(金煌芒)» }\end{array}$ & 0,2 & 0,6 & 7,06 & 0,5 & 9,2 & 23,0 & 0,01 & 0,04 & 0,6 \\
\hline $\begin{array}{c}\text { «Mango variety } \\
\text { Tianyangxiangmang } \\
\text { (田阳香芒) } \\
\end{array}$ & 0,3 & 0,6 & 13,1 & 0,9 & 9,7 & 76,0 & 0,02 & 0,05 & 0,5 \\
\hline
\end{tabular}

Показники хімічного складу манго коливаються в залежності від сорту та кліматичних умов вирощування. Одночасно було відмічено, що в нестиглих плодах манго вміст масової частки $\beta$-каротину виший, при повному дозріванні вміст знижується в двічі. При тому, що стигли плоди місять велику кількість вітаміну С, на смак кислота не відчувається. Значно вищі показники, масової частки розчинних сухих речовин, та моно-і дисахаридів свідчать про високу калорійність плодів. Середня енергетична цінність, калорійність манго складає 40,69 ккал або 170,49 кДж, Одночасно необхідно відмітити, що стиглий плід манго можливо віднести до продуктів 3 так званою мінусова калорійністю. На перетравлення манго, організм витрачає енергії в декілька разів більше калорій, ніж міститься в м'якоті плоду.

В Україні пюре мангове поступає за імпортом в одиницях пакування, як і пюре бананове асептичного консервування. Було проведено дослідження зразків пюре з манго різних постачальників, Shanghai Jinghuai Biotechnology Co., Ltd.( 上海靖淮生物技术有限公司) Китай, Paradise Ingredients commercial Team, Коста-Рика, JADLI FOODS PVT.LTD, Індія. За технологічними та сенсорними параметрами, пюре асептичного консервування з манго за зовнішніми ознаками виглядає, як однорідна протерта маса, в деякіх зразках відмічається одиничні точкові вкраплення темного кольору та невелика кількість затверділих крупинок м'якоті, також в деяких одиницях пакування присутня відшаровування рідини. Смак натуральний, добре виражений, властивий свіжому манго після термічного оброблення. Колір пюре насичено жовтий однорідний за всією масою, властивий натуральному кольору пюре 3 манго. Результати досліджень хімічного складу зразків пюре наведено в табл. 9.

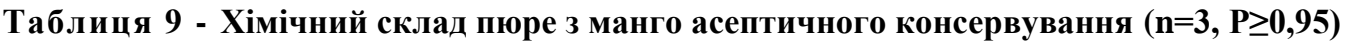

\begin{tabular}{|c|c|c|c|c|c|c|}
\hline \multirow{3}{*}{ Назва показника } & \multicolumn{6}{|c|}{ Зразки фірм - постачальників } \\
\hline & \multicolumn{2}{|c|}{$\begin{array}{c}\text { Biotechnology Co. Ltd. } \\
\text { (上海靖淮生物技术有限公司) } \\
\text { Китай }\end{array}$} & \multicolumn{2}{|c|}{$\begin{array}{c}\text { Paradise Ingredients } \\
\text { commercial Team, } \\
\text { Коста-Рика }\end{array}$} & \multicolumn{2}{|c|}{$\begin{array}{l}\text { JADLI FOODS } \\
\text { PVT.LTD } \\
\text { Індія }\end{array}$} \\
\hline & № 1 & № 2 & № 1 & № 2 & № 1 & № 2 \\
\hline 1 & 2 & 3 & 4 & 5 & 6 & 7 \\
\hline $\begin{array}{l}\text { Масова частка розчинних сухих } \\
\text { речовин, } \% \text {, }\end{array}$ & 16,0 & 16,0 & 14,1 & 14,1 & 13,5 & 13,5 \\
\hline Масова частка білку, г & 0,5 & 0,5 & 0,5 & 0,5 & 0,5 & 0,5 \\
\hline Масова частка жиру, г & 0,1 & 0,1 & 0,2 & 0,2 & 0,1 & 0,1 \\
\hline Масова частка пектину, г & 0,6 & 0,6 & 0,5 & 0,5 & 0,5 & 0,5 \\
\hline
\end{tabular}


Закінчення табл. 9.

\begin{tabular}{|c|c|c|c|c|c|c|}
\hline 1 & 2 & 3 & 4 & 5 & 6 & 7 \\
\hline Масова частка $\beta$-каротин, мг \% & 9,0 & 9,0 & 8,6 & 8,6 & 9,0 & 9,0 \\
\hline $\mathrm{pH}$ & 3,5 & 4,2 & 3,8 & 4,3 & 3,8 & 4,4 \\
\hline $\begin{array}{llr}\text { Масова } & \text { частка } & \text { титрованих } \\
\text { кислот } & \text { (у розрахунку на } \\
\text { лимонну кислоту), \% } & \\
\end{array}$ & 0,58 & 0,42 & 0,6 & 0,45 & 0,61 & 0,45 \\
\hline Масова частка летких кислот, \% & 0,01 & 0,01 & 0,01 & 0,01 & 0,01 & 0,01 \\
\hline Масова частка етилового спирту, \% & 0,2 & 0,2 & 0,2 & 0,2 & 0,2 & 0,2 \\
\hline $\begin{array}{l}\text { Масова частка } \\
\text { домішок, \% }\end{array}$ & 0,01 & 0,01 & 0,01 & 0,01 & 0,01 & 0,01 \\
\hline Масова частка вітаміну C, мг \% & 31,5 & 31,5 & 28,9 & 28,9 & 27,3 & 27,3 \\
\hline Масова частка вітаміну $\mathrm{B}_{1}$, мг \% & 0,01 & 0,01 & 0,01 & 0,01 & 0,01 & 0,01 \\
\hline Масова частка вітаміну $\mathrm{B}_{2}$, мг \% & 0,01 & 0,01 & 0,01 & 0,01 & 0,01 & 0,01 \\
\hline Масова частка вітаміну РР,мг \% & 0,4 & 0,4 & 0,4 & 0,4 & 0,4 & 0,4 \\
\hline
\end{tabular}

При дослідженні зразків пюре 3 манго асептичного консервування, встановлено, що пюре виготовлюють $з$ додаванням, або без додавання консерванту. В зразках № 1, коливання показника рН від 3,5 до 3,8, а масова частка титрованих кислот, у розрахунку на лимонну кислоту складає, від $0,58 \%$ до 0,61 \%. В зразках № 2, коливання показника рН від 4,2 до 4,4, а масова частка титрованих кислот, у розрахунку на лимонну кислоту складає не більше ніж 0,45 \%. Додавання кислоти в пюре впливає на показник $\mathrm{pH}$, що дозволяє корегувати параметри термічного оброблення, режиму стерилізації при асептичному консервуванні.

При використанні пюре асептичного консервування для виробництва продуктів дитячого харчування особливо функціонального призначення, необхідно контролювання вмісту кислоти, яка в даному випадку являється консервантом.

Результати проведених досліджень увійдуть в основу подальших прикладних та фундаментальних досліджень. На основі отриманих даних будуть створенні єдині технологічні вимоги показників якості та безпечності, які будуть відображенні в нормативній та технологічній документації на виробництво продуктів функціонального призначення для дитячого харчування.

\section{References}

1. Shulyak, O. V. (2014). Infektsiyi sechostatevih shlyahiv: pielonefrit // Ukrayinskiy medichniy chasopis, 4, 32 - 41. Retrieved from https://www.umj.com.ua/article/77841/infekcii-sechostatevix-shlyaxivpiyelonefrit [in Ukrainian].

2. Sayt derzhavnoyi sluzhbi statistiki Ukrayini // Statistichna Informatsiya, Retrieved from https://www. ukrstat. gov. ua https://www.umj.com.ua/article/77841/infekcii-sechostatevix-shlyaxiv-piyelonefrit [in Ukrainian].

3. Shushpanov, D. (2017). Determinanti zdorov'ya naselennya Ukryyini: ekologichniy vimir // Regionalni aspekti rozvitku produktivnih sil Ukrayini. 22, 132 - 142. https://doi.org/10.35774/rarrpsu2017.22.132

4. Natsionalne byuro statistiki KNR. (2019) // Kitayskiy statistichniy schorichnik, Pekin: Kitay Statistics Press, 中华人民共和国国家统计局. 中国统计年鉴[M]. 北京: 中国统计出版社.

5. Natsionalne byuro statistiki, Retrieved from http://www.stats.gov.cn/tjsj/ndsj.

6. Informatsiyna merezha Kitayu. Retrieved from http://www.chyxx.com/industry/ 201701/489699.html.

7. Dityachiy fond OON, YuNISEF: Retrieved from https://www.unicef.org.

8. Produkti pereroblennya fruktiv ta ovochiv. Refraktometrichniy metod viznachennya vmistu rozchinnih suhih rechovin [Fruit and vegetable processing products. Refractometric method for determining the content of soluble dry matter]. (2015). DSTU 8402:2015 from $1^{\text {st }}$ July 2017. Kyiv: Derzhstandart Ukrainy. Retrieved from http://online.budstandart.com/ru/catalog/doc-page?id_doc=82515 [in Ukrainian].

9. Produkti pereroblyannya fruktiv ta ovochiv. Metodi viznachannya suhih rechovin abo vologi [Fruit and vegetable processing products. Methods for determining dry matter or moisture]. (2016). DSTU

7804:2015 from $1^{\text {st }}$ July 2017. Kyiv: Derzhstandart Ukrainy. Retrieved from http://online.budstandart.com/ua/catalog/doc-page?id_doc=80802 [in Ukrainian].

10. Produkti pereroblennya fruktiv ta ovochiv, konservi m'yasni ta m'yaso-roslinni. Metodi viznachennya vmistu zhiru [Fruit and vegetable processing products, canned meat and meat and vegetable products. 
Methods for determining fat content]. (2009). DSTU 4941:2008 from $1^{\text {st }}$ August 2009. Kyiv: Derzhstandart Ukrainy. Retrieved from http://online.budstandart.com/ua/catalog/docpage? id doc $=82717$ [in Ukrainian].

11. Frukti, ovochi ta produkti yih pereroblyannya. Konservi m yasni ta m`yaso-roslinni. Gotuvannya prob do laboratornih analiziv [Fruits, vegetables and products of their processing. Canned meat and meat and vegetable. Preparation of samples for laboratory tests]. (2010). DSTU 7040:2009 from $1^{\text {st }}$ January 2011. Kyiv: Derzhstandart Ukrainy. Retrieved from http://online.budstandart.com/ua/catalog/docpage?id_doc $=83184$ [in Ukrainian].

12. Frukti, ovoch ta produkti pereroblyannya, konservi m`yasn ta m`yaso-roslinni. Metod viznachannya pH [Fruits, vegetables and processed products, canned meat and meat and vegetable. Method for determining $\mathrm{pH}$. (2010). DSTU 6045:2008 from $1^{\text {st }}$ July 2009. Kyiv: Derzhstandart Ukrainy. Retrieved from http://online.budstandart.com/ua/catalog/doc-page?id_doc=82522 [in Ukrainian].

13. Produkti pereroblennya fruktiv ta ovochv. Metodi viznachannya vtaminu $C$ [Fruit and vegetable processing products. Methods for determining vitamin C]. (2015). DSTU 7803:2015 from $1^{\text {st }}$ April 2016. Kyiv: Derzhstandart Ukrainy. Retrieved from http://online.budstandart.com/ua/catalog/docpage?id_doc=i80801/ [in Ukrainian].

14. Produkti pereroblennya fruktiv ta ovochiv. Metodi viznachannya vitaminiv B1 i B2 [Fruit and vegetable processing products. Methods for determining vitamins B1 and B2]. (2017). DSTU 7988:2015 from $1^{\text {st }}$ January 2017. Kyiv: Derzhstandart Ukrainy. Retrieved from http://online.budstandart.com/ua/catalog/doc-page.html?id_doc=80979 [in Ukrainian].

15. Produkti pereroblennya fruktuv ta ovochuv. Metodi viznachannya tsukruv [Fruit and vegetable processing products. Methods for determining sugars]. (2009). DSTU 4954:2008 from $1^{\text {st }}$ January 2009. Kyiv: Derzhstandart Ukrainy. Retrieved from http://online.budstandart.com/ua/catalog/docpage? id doc $=74270$ [in Ukrainian].

16. Frukti, ovochi ta produkti ih pereroblennya. Metod viznachannya vmistu karotinu [Fruits, vegetables and processed products. Method for determining carotene content]. (2005). DSTU 4305:2004 from $1^{\text {st }}$ July 2005. Kyiv: Derzhstandart Ukrainy. Retrieved from http://online.budstandart.com/ua/catalog/docpage?id_doc=74266 [in Ukrainian].

17. Produkti pererobki ovochiv ta fruktiv. Metod viznachennya vitaminu PP. [Fruit and vegetable processing products. Method for determination of vitamin PP.]. (1994). DSTU 2117-93 from 1 st July 1994 . Kyiv: Derzhstandart Ukrainy. Retrieved from http://online.budstandart.com/ua/catalog/docpage.html?id_doc $=84940$ [in Ukrainian].

18. Produkti pereroblennya fruktiv ta ovochiv. Metod viznachennya vmistu vitaminu A. [Fruit and vegetable processing products. Method for determining the content of vitamin A.]. (2009). DSTU 4940:2008 from $1^{\text {st }}$ January 2009. Kyiv: Derzhstandart Ukrainy. Retrieved from https://budstandart.ua/normativdocument.html?id doc=84069 [in Ukrainian].

19. Frukti, ovochi ta produkti pereroblennya. Metod viznachennya titrovanoyi kislotnosti [Fruits, vegetables and processed products. Method for determination of titratable acidity]. (2009). DSTU 4957:2008 2008 from $1^{\text {st }}$ January 2009. Kyiv: Derzhstandart Ukrainy. Retrieved from http://online.budstandart.com/ua/catalog/doc-page?id_doc=83280 [in Ukrainian].

20. Produktyi pererabotki plodov i ovoschey. Titrimetricheskiy metod opredeleniya pektinovyih veschestv [Fruit and vegetable processing products. Titrimetric method for the determination of pectin substances].

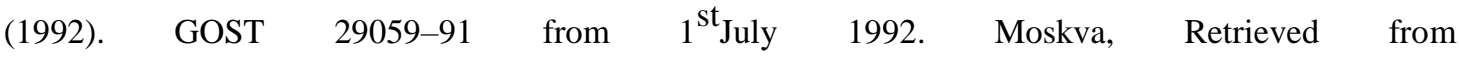
http://docs.cntd.ru/document/gost-29059. [in Russian].

Cite as

Мазуренко I.К., Yunbo Li, Shao Zhengzheng, Мельник О. Ю., Палвашова А.І. Сировина рослинного походження для виробництва продуктів дитячого харчування, функціонального призначення// Наук. пр. / Одес. нац. акад. харч. технологій. Одеса, 2020. Т. 84, вип. 2. С. 38 - 48.

Отримано в редакцію 11.08 .2020

Прийнято до друку $\quad 27.10 .2020$
Received $\quad 11.08 .220$

Approved 27.10.2020 